\title{
Influence of the Science Game "Sing and Floating" on Classification Ability of Children 5-6 Years Old at Kemala Bhayangkari Kindergarten School of Wangon
}

\author{
$1^{\text {st }}$ Winda Wahyu Dianty \\ UniversitasNegeri Yogyakarta \\ Yogyakarta, Indonesia \\ wahyuwinda24@gmail.com
}

\author{
$2{ }^{\text {nd }}$ Slamet Suyanto \\ UniversitasNegeri Yogyakarta \\ Yogyakarta, Indonesia
}

\begin{abstract}
The purpose of this research is knowed influence of the science game about sink and floating toward classificationability children at age 5-6 years old at KemalaBhayangkari kindergarten School of Wangon. This research is quasi experimentresearch, with kind of reseach is nonequivalent control group design. The population in this research is $\mathbf{5 0}$ children, the sample consisting of 36 children, consist of from 18 children like as experiment group and 18 children like as control group. The experiment group was given treatment with science game about sink and floating, while in control group the activities be held likes usually. The accumulation data with observation thread.
\end{abstract}

\section{INTRODUCTION}

Children is gift from Allah with fantastic potential, especially at the age of 0-6 years. Growth and development his brain reached $50 \%$ from the growth of a whole, so known as a golden age. In this period the provision of stimulation highly recommended, the aim is to developed the potential of children (Suyanto, 2005: 3-4).

Children is the unique personal, so the process of learning is also unique. Provided the stimulation must be adjusted with characteristic of children. The favorite activities of children is playing, because give a sense of happy, freedom just be yourself, free to chose a game, should be able to play the role of having the character of symbolic, children will be active motion, both physically and psychological to obtain self satisfaction (Hughes, 2010: 4-5). One of the activity of playing that can activate senses children is a science game. Science for the children is everything that found, amazing and interesting,
Which data in the result then to analysis and to test by t-test of statistic to see different between experiment group with control group. Based on the result of the paired sample $t$-test in experiment group, obtain $p$ value is $0,000<0,05$. The difference statistically significant, $t$ count-22,039 $\leq t$ table1,739. While in independent $t$-test obtained the value of $t$ count $-13,567 \leq t$ table 1,690 . So, based on the analysis the result is indicated there are influence from science game about sink and floating toward classification ability children at the age 5-6 years old.

Keywords: Science game about sink and float, classification ability.

and gave stimulation of children to investigate (Nugraha, 2005: 14).

On this science process, children will be active to know the truth of the experiment. Children will learn by sensory to observe, classifying, estimate, and calculating (Yulianti, 2010: 42-43). Classification is skill in the process of science, passed in a conference the experts science on American Association for the Advance of Science (Nugraha, 2005: 126).

Classification activities is expected can give positive impact to children, such as have proficiencyin choose and sort out some things are best for themselves. Sandra Crosser (2005) revealed that children age 5 years old can classify the same object. Characteristic classification on children 5-6 year is can classified the objects based on a particular category. Supporting that SaramadanClements (2009: 88-89) explain the topic of classification for kindergarten children is 
"classification: object can be grouped based on attributes and quantified".

Suyanto (2005: 159) explain about the topic of science what was interesting for children, one of them is science game about sink and floating. When the children do that experiment, children will be understand the object which sink and floating, and thend classify it to the same category.

Based on an examination in KemalaBhayangkari kindergarten of wangon, the activity still focused to worksheets with classical method. So, the sensory of the child less stimulated, les got experience of classification. Based on this researchers privides treatment of science game about sink and floating to know the influence science game about sink and floating towards classification ability children 5-6 years old in KemalaBhayangkari Kindergarten of Wangon.

\section{METHODS}

\section{Type of Research}

The research is quasi experiment, on a quasi experiment not all experiment condition could be fungtions fully to control other variables that affects (Sugiyono, 2013: 116). Experimental methods chosen to know the influence of science game about sink and floating towards classification ability children 5-6 years old.

.The design used pre-test post-test nonequivalent control group design, consist are two groups there are experiments group and control group. In the experimen group was given treatment with science game about sink and floating, but in the control group still using convensional method. Design of the the research as follows.

Table 1.Design of the research

\begin{tabular}{|l|c|c|c|}
\hline Group & Pretest & Treatment & Posttest \\
\hline Control & $\mathrm{O}_{1}$ & - & $\mathrm{O}_{2}$ \\
\hline Experiment & $\mathrm{O}_{1}$ & $\mathrm{X}$ & $\mathrm{O}_{2}$ \\
\hline
\end{tabular}

Keterangan:

$\mathrm{O}_{1} \quad$ = test of classification ability (pretest)

$\mathrm{O}_{2}=$ test of classification ability (posttest)

$\mathrm{X}=$ science game about sink and floating

A stage in this study is: 1) manufacture and trial instruments, 2) do Prasurvey and permits to the kindergarten, 3) Coordinate with teachers and giving brieving on the science game about sink and floating, 4) do pretest on each research group, 5) apply the treatment science game about sink and floating on experiment class, 6) do posttest on each research group, and 7) do data analysis.

\section{Research Subject}

Population in this research is all children 5-6 years old in KemalaBhayangkari Kindergarten of Wangon, consist of 50 children. The sample consisting of 36 children, devided into two groups, consist of from 18 children like as experiment group and 18 children like as control group.

\section{Technique and instrument of Data Collection}

Observation techniques used in this research, to observe influence science game about sink and floating towards classification ability. Observation guidelines used to collect data classification ability. The assessment do with notes classification ability in sheet of observation. Then analyzed the form of score 0 and 1 . Score " 0 " used when the children not able to to classification, and score "1" when the children be able to classification (Sugiyono, 2012: 134). Next total a score will be convert in the scala of 100 to make easier for the calculation of data analysis. An indicator that used in this research as follows.

Table 2.Indicator in this research

\begin{tabular}{|c|c|}
\hline Indicator & Assesment item \\
\hline \multirow{4}{*}{$\begin{array}{l}\text { Classify object } \\
\text { based on one } \\
\text { category }\end{array}$} & 1. Classify object sink \\
\hline & 2. Classify object floating \\
\hline & 3. Classify object big \\
\hline & 4. Classify object small \\
\hline \multirow{4}{*}{$\begin{array}{l}\text { Classify object } \\
\text { based on two } \\
\text { category }\end{array}$} & 5. Classify object sink a big \\
\hline & 6. Classify object sink a small \\
\hline & 7. Classify object floating a big \\
\hline & $\begin{array}{l}\text { 8. Classify object floating a } \\
\text { small }\end{array}$ \\
\hline
\end{tabular}

\section{Statistic Analyses}

The testing of hypotheses use parametric statistics. To know a differences in the treatment of two group, used t-test namely paired sample t-test and independent sample t-test. The data has been collected, then the calculated using Microsoft office excel 2007, and tested with SPSS 16. for windows.

\section{RESULT}

The observation resut of classification ability to summarize about output data with pretest and posttest, either of experiment group or control group. At or to pretest group, the activity going on ussualy. Whereas the postestgroup given treatment with 
science game about sink and floating. The embrace discription about pretest data and posttest data ability classificated like this.

Table 3.Pretest \& Posttest Data

\begin{tabular}{|l|r|r|r|r|}
\hline \multirow{2}{*}{} & \multicolumn{2}{|c|}{ Pretest } & \multicolumn{2}{c|}{ Posttest } \\
\cline { 2 - 5 } N Valid & \multicolumn{1}{|c|}{18} & \multicolumn{1}{c|}{ KK } & \multicolumn{1}{c|}{ KE } & \multicolumn{1}{c|}{ KK } \\
\hline \multicolumn{1}{|c|}{ Missing } & \multicolumn{1}{|c|}{18} & \multicolumn{1}{l|}{18} & \multicolumn{1}{c|}{18} \\
\hline Mean & 38,27 & 37,4 & 93,61 & 42,9 \\
\hline Median & 37,35 & 33,2 & 99,6 & 41,5 \\
\hline Minimum & 16,6 & 24,9 & 83 & 33,2 \\
\hline Maximum & 66,4 & 58,1 & 99,6 & 66,4 \\
\hline Sum & 688,9 & 672 & 1685 & 772 \\
\hline
\end{tabular}

Keterangan:

$\mathrm{KE}=$ Experiment group

$\mathrm{KK}=$ Kontrol group

To see from result of pretest and postest like that, trully before to given treatment, the start score ability clssificated group and control group is relatve same, whereas after to giving treatment that's is game of science about sink and float occurred increased significant score toward introduction ability classificate on the eksperiment group. The control groub also increasing, but is not to significant because not to given anything treatment.

Furthermore, this data to analysis for examine hypothesis by paired sample t-test and independent sample t-test, ensuing be result analysis data of classificated ability.

Table 4.Output test of paired sample $t$ testclassification experiment group

\begin{tabular}{|c|c|c|c|c|c|c|c|}
\hline \multicolumn{5}{|c|}{ Paired Differences } & \multirow[b]{3}{*}{$\mathrm{t}$} & \multirow[b]{3}{*}{$\mathrm{df}$} & \multirow{3}{*}{$\begin{array}{c}\text { Sig. } \\
2- \\
\text { tailec }\end{array}$} \\
\hline \multirow[b]{2}{*}{ Mean } & \multirow{2}{*}{$\begin{array}{l}\text { Std. } \\
\text { Devia } \\
\text { tion }\end{array}$} & \multirow{2}{*}{$\begin{array}{l}\text { Std. } \\
\text { Error } \\
\text { Mean }\end{array}$} & \multicolumn{2}{|c|}{$\begin{array}{c}95 \% \\
\text { Confidence } \\
\text { Interval of } \\
\text { the } \\
\text { Difference }\end{array}$} & & & \\
\hline & & & $\begin{array}{c}\text { Lowe } \\
\mathrm{r}\end{array}$ & Upper & & & \\
\hline 5.533 & $\begin{array}{c}10.65 \\
2\end{array}$ & 2.510 & $\begin{array}{c}- \\
60.63 \\
0\end{array}$ & $\begin{array}{c}- \\
50.03 \\
6\end{array}$ & $\begin{array}{c}- \\
22.03 \\
9\end{array}$ & 17 & .000 \\
\hline
\end{tabular}

So heavily relies result of paired sample t-test, by using degree level 0,05 can be aconclusion that's Ho is to push away, because the p score is 0,00 that's mean is more litle than $\alpha$, or $p<0,05$. The different is significant by statistical can be to see at the $\mathrm{t}$ score $-22,039 \leq \mathrm{t}$ table 1,739 until can be inferential that's different between pretest data classification ability at the eksperiment group. Whereas the result experiment of paired sample ttest pretest and posttest classification ability at the control group that like this.

Table 5.Output test of paired sample ttestclassification control group

\begin{tabular}{|c|c|c|c|c|c|c|c|}
\hline \multicolumn{5}{|c|}{ Paired Differences } & \multirow[b]{3}{*}{$\mathrm{t}$} & \multirow[b]{3}{*}{ df } & \multirow{3}{*}{$\begin{array}{c}\text { Sig. } \\
2- \\
\text { tailed }\end{array}$} \\
\hline & \multirow{2}{*}{$\begin{array}{c}\text { Std. } \\
\text { Devia } \\
\text { tion }\end{array}$} & \multirow{2}{*}{$\begin{array}{l}\text { Std. } \\
\text { Error } \\
\text { Mean }\end{array}$} & \multicolumn{2}{|c|}{$\begin{array}{c}95 \% \\
\text { Confidence } \\
\text { Interval of } \\
\text { the } \\
\text { Difference }\end{array}$} & & & \\
\hline Mean & & & $\begin{array}{c}\text { Lowe } \\
\mathrm{r}\end{array}$ & Upper & & & \\
\hline $\begin{array}{c}- \\
5.533\end{array}$ & $\begin{array}{c}11.02 \\
5\end{array}$ & 2.598 & $\begin{array}{c}- \\
11.01 \\
6\end{array}$ & -.050 & $\begin{array}{c}- \\
2.129\end{array}$ & 17 & .048 \\
\hline
\end{tabular}

So heavily relies result of paired sample t-test, by using degree level 0,05 can be aconclusion that's Ho is to push away, because the p score is 0,048 that's mean is more litle than $\alpha$, or $p<0,05$. The different is significant by statistical can be to see at the $\mathrm{t}$ score $-2,129 \leq \mathrm{t}$ table 1,739 until can be inferential that's different between pretest data classification ability at the control group. Whereas the result of independent sample t-test classification ability at the control group that like this. 
Table 6.Output independent sample t-test

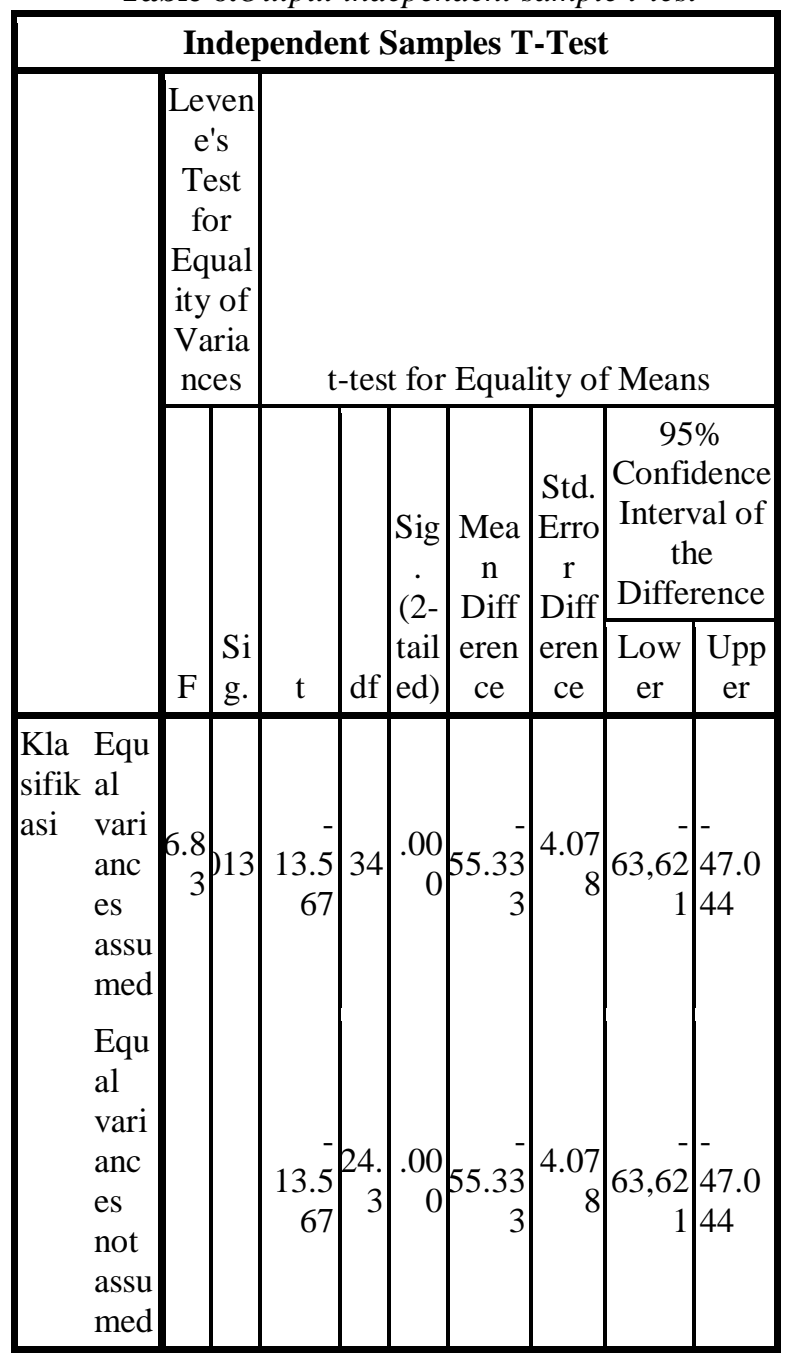

So heavily relies result of independent sample ttest, by using degree level 0,05 can be a conclusion that's Ho is to push away, because the p score is 0,000 that's mean is more litle than $\alpha$, or $p<$ 0,005 . The different is significant by statistical can be to see at the $\mathrm{t}$ score $-13.567 \leq \mathrm{t}$ table 1,690so can be inferential that'sthere are the significant influence from science game about sink and floating toward classification ability.

Table 7.Recapituulation of examine result t-test and independent t-test classification

\begin{tabular}{|l|c|c|}
\hline & $\begin{array}{c}\text { KelompokK } \\
\text { ontrol }\end{array}$ & $\begin{array}{c}\text { KelompokE } \\
\text { xperiment }\end{array}$ \\
\hline Mean pretest & 37,4 & 38,27 \\
\hline Mean posttest & 42,9 & 93,61 \\
\hline t pairedt-test & $-2,129$ & $-22,039$ \\
\hline $\begin{array}{l}\text { t } \text { independent } t \text { - } \\
\text { test }\end{array}$ & \multicolumn{2}{|c|}{-13.567} \\
\hline
\end{tabular}

the strenght from recapitulation table on top, $\mathrm{t}$ account from examine paired t-test control group is $2,219 \leq \mathrm{t}$ table 1,739 , at the eksperiment group can be conclusion value of $t$ account $-13,567 \leq t$ table as big as 1,690. Based on the analysis the result is indicated there are influence from science game about sink and floating toward classification ability children at the age 5-6 years old.

\section{DISCUSSION}

The classification ability is the most must be introduced to children. Sandra Crosser (2005) revealed that children age 5 years old can classify the same object. Classification activities is expected can give positive impact to children, such as have proficiencyin choose and sort out some things are best for themselves. Reys (1998: 90-94) revealed that classification is capability a very fundametal to study the real world, classification can help the children to identified some objects.

Liu (2007:6) explained that the activity of collecting and classify can be conducted by using object that in in around the child. Supporting that Jackman (2012:151) revealed that collecting and classify the object based on the common characteristics such as size, shape, and colour. Next Seefeldt, (2008: 392-401) explain that classify is grouping the same object or having the equality, example in science games about sink and floating is the children classify object based on the same characteristic of which object sink and object floating.

Next, there are research result by Tri Widyakto (2014) revealed that the science game influence to cognitive development children age 5-6 years. That research result becomes the basis for this research, with a focus research is science game to cognitive development. Cognitive development that measured in this research in the classification ability.

\section{CONCLUSION}

Based on observation and testing data using SPSS obtained t count pairedt-test control group $2,129 \leq \mathrm{t}$ table 1,739 , while in experiment group, obtain $\mathrm{p}$ value is $0,000<0,05$. The difference statistically significant, $\mathrm{t}$ count $-22,039 \leq \mathrm{t}$ table 1,739 . While in independent $t$-test obtained the value of $\mathrm{t}$ count $-13,567 \leq \mathrm{t}$ table 1,690 . Based on the analysis the result is indicated there are influence from science game about sink and floating toward classification ability children at the age 5-6 years old. 


\section{References}

Sugiyono. (2012).

MetodePenelitianKuantitatifKualitatifdan

$R \& D$. Bandung: Alfabeta.

Hughes, F. P. (2010). Children, play, and development. USA: SAGE Publications.

Suyanto, Slamet. (2005). DasardasarPendidikanAnakUsiaDini. Yogyakarta: Hikayat Publishing.

Nugraha,

Ali. (2005). PengembanganPembelajaranSainspadaanakus iadini.

Jakarta: DepartemenPendidikanNasionalDirektoratJend ralPendidikanTinggi.

Yulianti, Dwi. (2010). BermainSambilBelajarSains di tamankanak-kanak. Jakarta: Indeks.

Crosser, Sandra. (2005). Characteristics of Thinking.

Sarama, J \& Clements, D.H. (2009). Building blocks and cognitive building blocks playing to know the world mathematically. American Journal of Play. 1, 313-337.

Sugiyono.(2013). StatistikaUntukPenelitian. Bandung: Alfabeta.

Jackman, H. L. (2012). Early education curiculum : a child's connection to the world, fifth edition international edition. China : Wadsworth Cengage Learning.

Seefeldt, C. \&Wasik, B. A. (2008).Pendidikananakusiadini. (Terjemahan Pius Nasar). Jakarta: Indeks.

Liu, X. (2007).Elementary school students' logical reasoning on rolling.International Journal Of Technology And Design Education, 10, 3-20.

Reys Robert E., Marilyn N. Suydam, Mary M. Lindquist, Nancy L. Smith. 1998. Helping Children learn Mathematics $5^{\text {th }}$ Edition. United States of America: A Viacom Company.

Tri Widyakto. 2014. PengaruhPermainanSainsterhadapPerkemb anganKognitifAnakUsia 5-6 Tahun Di TK AisyiyahPajang. ArtikelPublikasiUniversitas Muham-madiyah Surakarta. 